\title{
PERFORMANCE ANALYSIS AND OPTIMIZATION \\ OF THE UNIVERSITY OF PENNSYLVANIA RETROFITTED SOLAR HEATED PHILADELPHIA ROW HOME
}

\section{Progress Report}

for Period October 15, 1976 - August 15, 1977

Noam Lior

University of Pennsylvania Philadelphia, Pennsylvania 19104

August 1977

\section{Prepared for}

THE U. S. ENERGY RESEARCH AND DEVELOPMENT ADMINISTRATION

UNDER CONTRACT NO. EG-77-S-02-4142. ${ }^{\star 0000}$ 


\section{DISCLAIMER}

This report was prepared as an account of work sponsored by an agency of the United States Government. Neither the United States Government nor any agency Thereof, nor any of their employees, makes any warranty, express or implied, or assumes any legal liability or responsibility for the accuracy, completeness, or usefulness of any information, apparatus, product, or process disclosed, or represents that its use would not infringe privately owned rights. Reference herein to any specific commercial product, process, or service by trade name, trademark, manufacturer, or otherwise does not necessarily constitute or imply its endorsement, recommendation, or favoring by the United States Government or any agency thereof. The views and opinions of authors expressed herein do not necessarily state or reflect those of the United States Government or any agency thereof. 


\section{DISCLAIMER}

Portions of this document may be illegible in electronic image products. Images are produced from the best available original document. 


\section{Abstract}

The design, specification and purchasing phase of the instrumentation and data acquisition system needed for the performance analysis and optimization of the solar heating system, and for the acquisition of Philadelphia weather and insolation data is complete, and is described briefly. A subroutine for the analysis of the effects of the control logic and limits on the performance of the solar system has been written and implemented into the University of Pennsylvania general program SOLSYS. The installation of the instruments is ongoing. A contract renewal proposal was written to conduct the data acquisition, and system analysis and optimization beginning from the heating season $1977 / 8$. 
1. INTRODUCTION

This project can be seen to consist of two major parts:

A. Design and construction of the instrumentation and data acquisition system.

B. Performance testing, analysis and optimization of the solar heating system, as well as acquisition of weather and solar data for Philadelphia.

The official starting data of the contract is October 15, 1976; however, the actual contract papers were sent to the University of Pennsylvania and signed only at the end of December 1976. We could not therefore start the work (i.e. incur expenses) before that later data. The major consequence of this delay was that we could not complete the needed instrumentation system in time for the 1976/.7 heating season, but we would be ready for the 1977/8 heating season. A contract renewal proposal to allow this is being sent to ERDA alongside this report.

\section{ACCOMPLISHMENTS}

The major accomplishments under this contract so far are:

2.1 Design of the Instrumentation and Data Acquisition System.

The design of the instrumentation system is complete. This included:

(1) Definition of the solar system performance critoria, for the calculation of which the measurements are made.

(2) Selection of appropriate types of instruments for the measurement of temperature, flow, pressure, insolation, wind velocity and direction, humidity, and electric power. 
(3) Design of appropriate instrument installation techniques, in consultation with avallable pertinent standards and recommended practices issued by the ASHRAE, ASME, ISA, ASTM, BS and DIN. The experience accumulated at the University of Pennsylvnaia in the area of solar component testing was fully utilized.

(4) Design of appropriate sensor signal conditioning methods, and selection of an effective and economical method for data acquisition.

In particular, the transient nature of many of the measured parameters requires a measurement frequency of the order of one measurement per minute or better. Since our system has approximately $80^{\prime}$ channels, this would result in the acquisition of a very large quantity of data over the year. To alleviate this problem, two major steps were taken: large capacity magnetic digital tape recording $\left(1 / 2^{\prime \prime} \times 1200^{\prime}\right.$ reel) of the data is used, and a technique of digital data averaging, available in the chosen data acquisition system was employed. In this technique, the most transient channels are scanned continuously (i.e., at a frequency of 1 channel per 8 seconds in our system), the results are digitally averaged by the DAS, and then the averages are recorded at a slower frequency, say once per 80 seconds.

\subsection{Specification and Purchasing}

All the instrumentation to be purchased was fully specified, and in most cases requests for quotations (RFQ-S) were issued to vendors. A careful 
comparison of technical specifications, costs, delivery periods, and service arrangements was made before the actual purchase order was issued. Al1 the instrumentatation is now either on order. or has already been received by us.

The selecion of performance criteria and the specification of instruments was aided by publications of The Solar Heating and Cooling Performance Evaluation Committee ${ }^{1}$ and of NBS/ERDA ${ }^{2}$.

A detajled topical report describing the design, specification, selection, purchase, calibration and installation of the instrumentation system is now under preparation. The highlights are presented in Appendix $A$ to this progress report.

\subsection{Control Logic Analysis Program}

A subroutine for the analysis of the effects of the control logic and limits on the performance of the solar heating system was added to the University of Pennsylvania general computer program SOLSYS. SOLSYS has the capability of analyzing the performance of solar heating systems and components and has been used to design the system on the subject row home.

The subroutine.will allow the planning of effective optimization experiments, which are part of the ongoing project, and would be tested by the actual experimental results.

\subsection{Publications}

The following publications related to the project appeared during this period:

\footnotetext{
l Hale, M. J., et al., "Instrumentation Installation Guidelines for the National Solar Heating and Cooling Program", USERDA Publication SHC-1006, August 4, 1976.

${ }^{2}$ Streed, E., et al., "Thermal Data Requirements and Performance Evaluation Proce-dures for the National Solar Heating and Cooling Demonstration Program", Publication NBSIR. 76-1137, National Bureau of Standards (Prepared for USERDA, Division of Solar Energy and for U.S.H.U.D., Division of Energy, August 1976).
} 
1. N. Lior, J. A. Lepore and S. Shore, "Residential Solar Heating Retrofit in the Urban Environment", Proceedings of the Joint Conference of the American Section of the International Solar Energy Society and the Solar Energy Society of Canada, August 15-20, 1976, Winnipeg, Manitoba, Canada. Also published in edited form as MEAM Report No. 76-10 in December 1976.

2: N. Lior, J. O'Leary and D. Edelman, "Optimized Spacing between Rows of Solar Collectors", Proc. International Solar Energy Society Conference (U.S. Section), June 6-10, 19.77, Orlando, FL.

3. S. Shore, J. A. Lepore and N. Lior, "Solar System Retrofit of Row Houses - A Proven Energy Conservation Method?", Proc. National Conference and Exhibition on Technology for Energy Conservation, June 8-10, 1977, Washington, DC.

A presentation on the project was made, and its typed contents submitted, at the USERDA Solar Heating and Cooling R\&D Branch Contractors Meeting at Reston, VA during August 8-10, 1977. This presentation is enclosed as Appendix A to this report.

Reprints of all above publications were submitted to ERDA during the abovementioned Contractors Meeting at Reston, VA.

2.4 Time Spent by Principal Investigator

$91.1 \%$ of the time formally al located in the proposal was devoted by the Principal Investigator to this project til August 15, 1977. Although only $8.9 \%$ remain til the end of the present contract period, the Principal. Investigator shall devote to this project significantly more, as part of a costsharing process.

\section{PLANNED WORK}

During the remaining period, til october 15,1977 , it is planned to complete the caljibration and installation of the instrumentation system. If the contract renewal proposal is approved by ERDA, solar heating performance analysis and optimization shail be conducted starting from the heating season $1977 / 8$. 


\section{APPENDIX}

Design and Specification Highlights of the

Instrumentation and Data Acquisition System 


\section{PERFORMANCE ANALYSIS AND OPTIMIZATION OF THE UNIVERSITY OF PENNSYLVANIA RETROFITTED SOLAR HEATED PHILADELPHIA ROW HOME}

U.S.E.R.D.A. CONTRACT NO, EG-77-S-02-4142,*000

PRINCIPAL INVESTIGATOR: DR, NOAM LIOR

DEPARTMENT OF MECHANICAL ENGINEERING AND APPLIED MECHANICS UNIVERSITY OF PENNSYL.VANIA

PHILADELPHIA, PENNSYLVANIA 19104 PROJECT MONITORS: MR, MICHAEL MAYBAUM, PROGRAM MANAGER
MR, WALTER ADAMS

ERDA SOLAR HEATING AND COOLING R\&D BRANCH CONTRACTOR'S MEETING RESTON, VA; AUGUST 8-10 
A. TO MONITOR AND ANALYZE THE PERFORMAIICE OF THE PHILADELPHIA ROW HOME WHICH WAS RETROFITTED TO SOLAR HEATING BY THE UNIVERSITY OF PENNSYLVANIA, AND TO EXAMINE ITS ACCEPTANCE IN THE URBAN ENVIRONMENT.

B. TO OPTIMIZE THE PERTORMANCE OF THE SYSTEM RELATIVE TO ENERGY--EFFICIENCY AND COST,

C. TO PROVIDE HOURLY WEATHER AND INSOLATIOIN DATA FOR PHILADELPHIA FOR A PERIOD OF TWO YEARS.

\section{PERFORMANCE EVALUATION CRITERIA}

1. SAVINGS IN FOSSIL FUEL

2. TOTAL THERMAL ENERGY LOADS

3. FRACTION OF THERMAL LOADS SUPPLIEJ) BY SOLAR ENERGY

4. SOLAR SYSTEIY ENERGY CONVERSIOIN EFFICIENCY

5. THERMAL PERFORMANCE OF MAJOR COMPONENTS *COllectors, WITH \& WITHOUT PARTIAI. SHAD ING

* STORAGE

* FREEZE pRotection DRAIN-DOWIN SYSTEM * HEAT EXCHANGERS

6. OCCUPANTS SYSTEM USE (DEMAND, TEMPERATURE, ETC.)

7. OPERATIONAL CHARACTERISTICS, CONTROLS, DEGRADATION

8. OPTIMIZATION: QUANTITY OF STORAGE, FLOW RATE, CONTROLS

9. ACCEPTANCE BY RESIDENTS, NEIGHBORHOOD, CITY GOVERNMENT

10. HOURLY SOLAR AND WEATHER-DATA FOR PHILADELPHI, 


\section{CLIMATOLOGICAL MEASUREMENTS}

INSOLATION

TOTAL: EPPLEY,ISP PYRANOMETER ( $\$ 990)$

DIFFUSE: EPPLEY PSP PYRANOMETER HITH SHADOWIBAND $(\$ 1690)$

WIiD

R.M. YOUNG CO, UVW PROPELLIER ANEMOMETER (\$1987)

\section{HUMIUITY}

WEATHERMEASURE HMIII SOLID STATE RELATIVE HUMIDITY SENSOR (\$772)

\section{TEMPERATURE}

ARI $100 \Omega$ PLATIHUM RTD (\$!?)

\section{TEMPERATURE MEASUREMENT}

EXCEPT FOR AIR TEMPERATURE DIFFLRENCES IN DUCTS, USE $100 \Omega$ MATCHED PLATINUM RESISTANCE TEMPERATURE DETECTORS (ARI, INC.) DUE TO HIGH STABIIITY AND LEVEL OF OUTPUT SIGNAL. COST (INCLUDING: TERMINAL HEAD): \$AT LACH 
PRESENT DAYY IJVHA-S NHD STABLE CURRENT SOURCES NLLOH SUFFICIENTIY PRECISE TEMPERATURE MEASURERENT PY TIE COHSTANT CURRENT, H-HIRE LEFTHOD

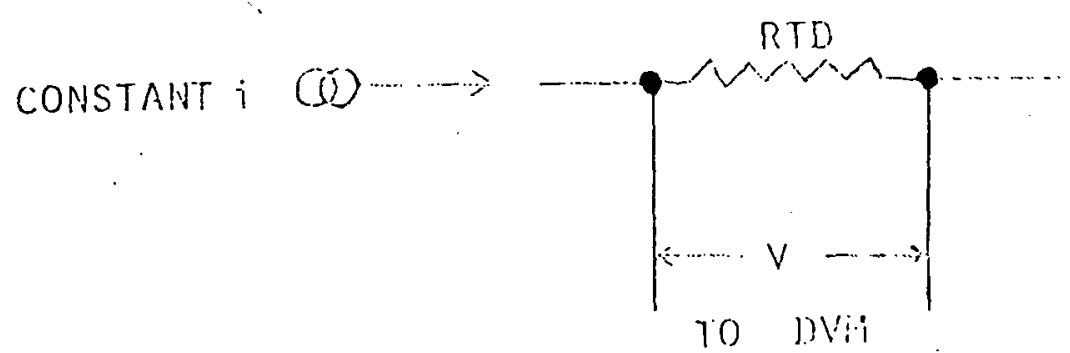

ADVANTAGES OF 4-HIRE COUSTANT CUENTH METIIOH):

"eliminate lead resistahcl errolis

* Simple inexpensive cikcuit

* increased (at least double) senuitivity

* linear output

"aliows deterhimation of tempefaibie differrehclis TO BETTER THAN 0.1 ${ }^{\circ} \mathrm{C}$ BY ARITHMEIIC SUETRACTION OF INDIVIDUAL RTD TEMPERATUKES, THUS RROVIDFS TEMPERATURE AND AT WITH SMALLEGT HUMABER OF: SENSORS (ANI) MEASUREMENT CHANNELS) 
10-JUNCTION TYPE K THERMOPILE, EACH JUNCTION PLACED IN THE CENTER OF ONE OF 10 DUCT SEGMENTS OF EQUAL CROSSSECTIONAL AREA:

PREMIX AIR STREAM UPSTEAM OF TEMPITRATURE HEASUREMENT SECTION.

FOLLOW ASHRAE STANJARD 41-66 "TLTHER:TURE MEASUREMENTS", 1966.

FLOH MELSUREMENT: GENEPNL'

MAIN PROBLEM IS THE COHRIHATIOH OF:

1) LOW FLOW RATE

2) SOME FLOWS HAVE A VERY WIDE RAIGE.

3) ELECTRICAL OUTPUT SIGNAL IS REOUJRED

4) HIGH ACCURACY IS REQUIRED

MAJOR APPLICABLE INSTRUMENTS:

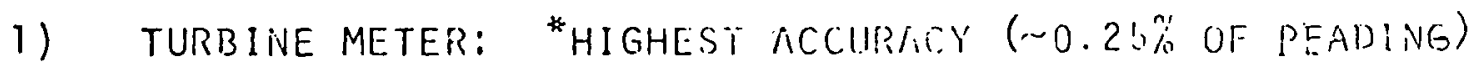
* bearing froblemís

2) target meter: *Reliable: ho moving parts

* Relatively high preggure. iJPOP.

3) MAGNETIC FL.OHIVE IER:

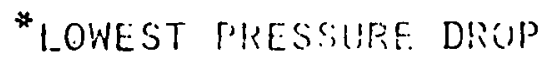

* highest cost
}

ALL ARE EXPENSIVE, 
SPECIFIC FLOWMETERS

\begin{tabular}{|c|c|c|c|c|c|}
\hline SYSTEM & FLUID & $\begin{array}{l}\text { MAXIMUM } \\
\text { FLOW }\end{array}$ & COMMENTS & MODEL & $\begin{array}{l}\text { TOTAL } \\
\text { PRICE }\end{array}$ \\
\hline Collector loop & water & $14 \mathrm{gpm}$ & & RAMAPO 1" (Target) & $\$ 719$ \\
\hline Demand loop & water & $8 \mathrm{gpm}$ & low head available & INVALCO $3 / 4^{\prime \prime}$ (Turbine) & 623 \\
\hline $\mathrm{DHW}$ & water & $12 \mathrm{gpm}$ & wide flow range needed & $\begin{array}{l}\text { FLOW TECHNOLOGY } 5 / 8 " \\
\text { (Turbine) }\end{array}$ & 1140 \\
\hline Warm air & atr & $1500 \mathrm{cfm}$ & $\begin{array}{l}\text { very low } \Delta P\left(\approx 0.05^{\prime \prime}\right. \\
\text { w.c. }) \text { for mea surement }\end{array}$ & $\begin{array}{l}\text { AIR MONITOR FAN-E } \\
\text { (averaged Pitot) }\end{array}$ & $\begin{array}{r}144+ \\
1300 ?\end{array}$ \\
\hline Furnace fuel & $\begin{array}{l}\text { fuel } \\
\text { ofl \#2 }\end{array}$ & $2 \mathrm{gph}$ & very low flow rate & CONAMETER CORP \#13 & 710 \\
\hline DHW Heater & $\begin{array}{l}\text { natura } \\
\text { gas }\end{array}$ & $75 \mathrm{cfh}$ & $\begin{array}{l}\text { gas supply pressure } \\
\text { very low: } 5.5^{\prime \prime} \text { w.C. }\end{array}$ & $\begin{array}{l}\text { AMERICAN METER AC- } 80 \\
\text { (DIAPHRAGM), } \triangle P=0.5^{\prime \prime} \\
\text { w.c.; with in-house } \\
\text { modification to provide } \\
\text { electric signal }\end{array}$ & -600 \\
\hline
\end{tabular}




\section{PRESSURE}

1) MECHANICAL INDICATING PRESSURE GAUGES

2) STRAin gauge tYPE TRANSDUCERS

\section{ELECTRIC POWER}

SOLAR LOOP CIRCULATION PUMP

DEMAND LOOP PUMP.

WARM AIR FAN

ALL USE LEEDS \& NORTHRUP \#759 TRANSDUCERS

KEEP VOLTAGE TERMINALS ALWAYS CONNECTED TO AVOID START AND STOP TRANSIENT ERRORS

\section{DATA ACQUISITIOIN SYSTEM}

*to avoid errors due to transients nND yet have a MANAGEABLE QUANTITY OF DATA, RECORD AVERAGES OF THE MOST TRANSIENT PARAMETERS EITHER BY INTEGRATION OF ANALOG SIGNAL PRIOR TO INPUT TO DAS, OR BY DIGITAL AVERAGING OF OUTPUTS FROM FREQUENT SCANS (PERFORMED INSIDE DAS). THUS, A SCAN EVERY 5-10 MINUTES IS. SUFFICIENT.

* RECORD DATA, ON

1) DIGITAL MAGNETIC TAPE, FOR COMPLETE PROCESSING.

2) WIDE-CARRIAGE PRINTER FOR IMMEDIATE DATA MONITORING AND FOR REDUNDANCY, 
University of Pennsylvania

PERFORMAICE AIIALYSIS AND OPTIMIZATION OF

THE UNIVERSITY OF PENIVSYLVANIA RETROFITTED

SOLAT HEATED PHILADELPHIA RON HOME

\section{INSTRUMENTATION TABLE}

MEASUREMENT

DESCRIPTION

\section{Climatological:}

HoOI

1001

1002

P001

$\vec{D}$

TOOI

V001

\section{Collector System:}

EPOOO

Elestrical power to circulation pump

P100

Circulation furip discharge

P101

P102

\section{Outdoor humidity}

Total insolation

Diffuse insolation

Outdoor barometric pressure

\section{Outdoor dry-bulb temperature}

Wind velocity arid direction (3-dimensional, UVW)

RANGE

SENSOR

MODEL

0 to $100 \% \mathrm{RH}$

0 to $1150 \mathrm{~W} / \mathrm{m}^{2}$ (0 to 365

Btu/hr.ft')

0 to $500 \mathrm{~W} / \mathrm{m}^{2}$ (0 to 158

Btu/hr.ft?)

98.2 to $105 \mathrm{kN} / \mathrm{m}^{2}$ (29" to 31 " $\mathrm{Hg})$

-40 to $50^{\circ} \mathrm{C}\left(-40 \cdot\right.$ to $\left.122^{\circ} \mathrm{F}\right)$

0 to $34 \mathrm{~m} / \mathrm{s}$ (0 to $80 \mathrm{mph}$ );

0 to $360^{\circ}$

0 to $1500 \mathrm{~W}$

0 to $413.7 . k: \% m^{2}$ gauge

(0 to 60 ,psig)

0 to $172.4 \mathrm{kiv} / \mathrm{m}^{2}$ gauge

(0 to 25 psig)

0 to $\pm 68.9 \mathrm{kiv} / \mathrm{m}^{2}$ gauge

(0 to $\pm 10 \mathrm{psig})$

WEATHERMEASURE

HMIII

EPPLEY PSP

EPPLEY PSP

with shadowband

$\mathrm{ARI}^{\dagger}$

R. M. Young $27004 / 21282 / 27503$

LEEDS \& NORT.HRUP 759

Indicating gauge

BELL \& HOWELL CEC 4-312-0002

BELL \& HOWELL CEC 4-312-0002

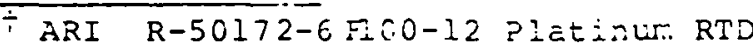




\begin{tabular}{|c|c|c|c|c|}
\hline & MEASUREMENT & DESCRIPTION & RANGE & $\begin{array}{l}\text { SENSOR } \\
\text { MODEL }\end{array}$ \\
\hline & $\frac{\text { Collector System }}{\text { P103 }}$ & $\begin{array}{l}\text { cont'd: } \\
\text { Inlet to storage tanks }\end{array}$ & $\begin{array}{l}0 \text { to } 413.7 \mathrm{kN} / \mathrm{m}^{2} \text { gauge } \\
(0 \text { to } 60 \mathrm{psig})\end{array}$ & $\begin{array}{l}\text { Indicating } \\
\text { gauge }\end{array}$ \\
\hline & $P, 04$ & Circulation pump suction & $\begin{array}{l}0 \text { to } 172.4 \mathrm{kN} / \mathrm{m}^{2} \text { abs } \\
(0 \text { to } 25 \mathrm{psia})\end{array}$ & $\begin{array}{l}\text { Indicating } \\
\text { gauge }\end{array}$ \\
\hline & T100 & Outlet from thermal storage tank \#1 (W.SDHWH*) & -10 to $110^{\circ} \mathrm{C}\left(14\right.$ to $\left.2.30^{\circ} \mathrm{F}\right)$ & 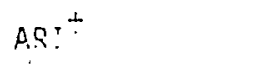 \\
\hline & T101 & Outlet from thermal storage tank \#2 & 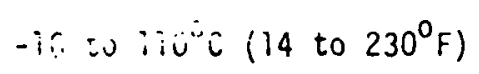 & ARI ${ }^{\dddot{\prime}}$ \\
\hline & T102 & Outlet from thermal storage tank \#3 & -10 to $110^{\circ} \mathrm{C}\left(14\right.$ to $\left.230^{\circ} \mathrm{F}\right)$ & $\operatorname{ARI}^{\dagger}$ \\
\hline & T103 & Inlet to first collector row & -10 to $110^{\circ} \mathrm{C}\left(14\right.$ to $\left.230^{\circ} \mathrm{F}\right)$ & $\operatorname{ARI}^{\dagger}$ \\
\hline & T104 & Inlet to second collector row & -10 to $110^{\circ} \mathrm{C}\left(14\right.$ to $\left.230^{\circ} \mathrm{F}\right)$ & $\mathrm{ARI}^{\dagger}$ \\
\hline & T105 & Inlet to third collector row & -10 to $110^{\circ} \mathrm{C}\left(14\right.$ to $\left.230^{\circ} \mathrm{F}\right)$ & $\operatorname{ARI}^{\dagger}$ \\
\hline$\vec{G}$ & T106 & Inlet to fourth collector row & -10 to $110^{\circ} \mathrm{C}\left(14\right.$ to $\left.230^{\circ} \mathrm{F}\right)$ & $A_{R}^{+}$ \\
\hline & $T 107$ & Inlet to fifth collector row & -10 to $110^{\circ} \mathrm{C}\left(14\right.$ to $\left.230^{\circ} \mathrm{F}\right)$ & $A R I^{\dagger}$ \\
\hline & T108 & Cutiei fron fiftin collector row & -10 to $110^{\circ} \mathrm{C}\left(14\right.$ to $\left.230^{\circ} \mathrm{F}\right)$ & $A R I^{\dagger}$ \\
\hline & T109 & Thermal storage tank inlet manifold & -10 to $110^{\circ} \mathrm{C}\left(14\right.$ to $\left.230^{\circ} \mathrm{F}\right)$ & $A R I^{\dagger}$ \\
\hline & $w 100$ & collector loop & $\begin{array}{l}0.09 \text { to } 0.9 \times 10^{-3} \mathrm{~m}^{3} / \mathrm{s} \\
(1.4 \text { to } 14 \mathrm{GPM})\end{array}$ & $\begin{array}{l}\text { RAMAPO } \\
1 \text { in. Mark V }\end{array}$ \\
\hline & WIOI & Inlet to storage tank & $\begin{array}{l}0.12 \text { to } 0.63 \times 10^{-3} \mathrm{~m}^{3} / \mathrm{s} \\
(2 \text { to } 10 \mathrm{GPM})\end{array}$ & $\begin{array}{l}\text { BELL \& OOSSETT } \\
\text { TB }-1 "\end{array}$ \\
\hline & W102 & Inlet to storage tank $\neq 2$ & $\begin{array}{l}0.12 \text { to } 0.63 \times 10^{-3} \mathrm{~m}^{3} / \mathrm{s} \\
\text { (2 to } 10 \mathrm{GPM})\end{array}$ & $\begin{array}{l}\text { BEL! \& COSSETT } \\
\text { TB - ?" }\end{array}$ \\
\hline & $4 ! 03$ & Iniet to storage tank $\neq 3$ & $\begin{array}{l}0.12 \text { to } 0.63 \times 10^{-3} \mathrm{~m}^{3} / \mathrm{s} \\
(2 \text { to } 10 \mathrm{GPM})\end{array}$ & $\begin{array}{l}\text { BELL \& GOSSETT } \\
\text { TB - }{ }^{\prime \prime}\end{array}$ \\
\hline
\end{tabular}

RANGE

SENSOR

* SCHWli - Solar Comestic Hot bater Heater

+ ARI R-50172 - 6F100-12 Platinum RTD 
(3)

\begin{tabular}{|c|c|c|c|}
\hline MEASLREMEIT & DESCRIPTION & RANGE & $\begin{array}{l}\text { SENSOR } \\
\text { MODEL }\end{array}$ \\
\hline Collector System: & $\begin{array}{l}\text { cont'd } \\
\text { outlet from storage tank } \# \text { l }\end{array}$ & $\begin{array}{l}0.12 \text { to } 0.63 \times 10^{-3} \mathrm{~m}^{3} / \mathrm{s} \\
\text { (2 to } 10 \mathrm{GPM})\end{array}$ & $\begin{array}{l}\text { BELL \& GOSSETT } \\
\text { TB - I" }\end{array}$ \\
\hline W105 & Outlet from storage tank \#2 & $\begin{array}{l}0.13 \text { to } 0.64 \times 10^{-3} \mathrm{~m}^{3} / \mathrm{s} \\
(2 \text { to } 10 \mathrm{GP} / 4)\end{array}$ & $\begin{array}{l}\text { BELL \& GOSSETT } \\
\text { TB } I^{\prime \prime}\end{array}$ \\
\hline W106 & Outlet from storage tank $\# 3$ & $\begin{array}{l}0.13 \text { to } 0.64 \times 10^{-3} \mathrm{~m}^{3} / \mathrm{s} \\
(2 \text { to } 10 \mathrm{GPM})\end{array}$ & $\begin{array}{l}\text { BELL \& GOSSETT } \\
T B-I "\end{array}$ \\
\hline \multicolumn{4}{|l|}{$\begin{array}{l}\text { Thermal Storage } \\
\text { System: }\end{array}$} \\
\hline$T 200$ & $\begin{array}{l}\text { Temperature distribution in thermal } \\
\text { storage tank } \ddot{\pi} i\end{array}$ & -10 to $110^{\circ} \mathrm{C}\left(14\right.$ to $\left.230^{\circ} \mathrm{F}\right)$ & $\operatorname{ARI}^{\dagger+\dot{t}}$ \\
\hline T201 & $\begin{array}{l}\text { Temperature distribution in thermal } \\
\text { storage tank \#1 }\end{array}$ & -10 to $110^{\circ} \mathrm{C}\left(14\right.$ to $\left.230^{\circ} \mathrm{F}\right)$ & $\operatorname{ARI}^{\dagger+}$ \\
\hline T202 & $\begin{array}{l}\text { Temperatire distribution in thermal } \\
\text { storage tank }=1\end{array}$ & -10 to $110^{\circ} \mathrm{C}\left(14\right.$ to $\left.230^{\circ} \mathrm{F}\right)$ & $A^{+t}$ \\
\hline T203 & $\begin{array}{l}\text { Temperature distribution in thermal } \\
\text { storage tank. } \# 1\end{array}$ & -10 to $110^{\circ} \mathrm{C}\left(14\right.$ to $\left.230^{\circ} \mathrm{F}\right)$ & $\mathrm{ARI}^{\dagger+}$ \\
\hline T204 & $\begin{array}{l}\text { Temperature distribution in thermal } \\
\text { sturage tank } \# \text { ? }\end{array}$ & -10 to $110^{\circ} \mathrm{C}\left(14\right.$ to $\left.230^{\circ} \mathrm{F}\right)$ & ARI $\div$ \\
\hline T205 & $\begin{array}{l}\text { Tamperature distribution in thermal } \\
\text { storage tank } \sharp i\end{array}$ & -10 to $110^{\circ} \mathrm{C}\left(14\right.$ to $\left.230^{\circ} \mathrm{F}\right)$ & $A R I^{-t}$ \\
\hline T206 & $\begin{array}{l}\text { Tariperacura discribution in thermal } \\
\text { scoráge tánk } \equiv 1\end{array}$ & -10 to $110^{\circ} \mathrm{C}\left(14\right.$ to $\left.230^{\circ} \mathrm{F}\right)$ & A.RI $I^{+\div}$ \\
\hline T207 & $\begin{array}{l}\text { Temperature distribution in thermal } \\
\text { stcrage tank } \$ 2\end{array}$ & -10 to $110^{\circ} \mathrm{C}\left(14\right.$ to $\left.230^{\circ} \mathrm{F}\right)$ & $\dot{A R} I^{+t}$ \\
\hline T208 & $\begin{array}{l}\text { Temperature distribution in thermal } \\
\text { storase tank } i ?\end{array}$ & -10 to $110^{\circ} \mathrm{C}\left(14\right.$ to $\left.230^{\circ} \mathrm{F}\right)$ & $A R I^{\circ \div}$ \\
\hline T209 & $\begin{array}{l}\text { Teilperature cistribution in thermal } \\
\text { sticráge tank }: Z \mathrm{Z}\end{array}$ & -10 to $110^{\circ} \mathrm{C}\left(14\right.$ to $\left.230^{\circ} \mathrm{F}\right)$ & $A R I^{\dagger t}$ \\
\hline T210 & $\begin{array}{l}\text { Temperature districution in thermal } \\
\text { storage tarik } ¥ \mathrm{i}\end{array}$ & -10 to $770^{\circ} \mathrm{C}\left(14\right.$ to $\left.230^{\circ} \mathrm{F}\right)$ & ARI \\
\hline$T 211$ & $\begin{array}{l}\text { Temperature distribution in thermal } \\
\text { storage tank } \$ 2\end{array}$ & -70 to $1710^{\circ} \mathrm{C}\left(14\right.$ to $\left.230^{\circ} \mathrm{F}\right)$ & $A R I^{*}$ \\
\hline
\end{tabular}


Thermal Storage

System cont'd

\section{T212}

$T 213$

Domestic Hot

F300

P300

P301

P302

$\bar{v}$
Water System:
Temperature distribution in thermal storage tank $\$ 2$

Temperature distribution in thermal storage tank \#2

Gas flow rate to DHW gas-fired heater

Inlet to SDhiWH

Outlet from SOHivH

Outlet from gas-fired neater

$\mathrm{T} 300$

T301

: $\mathrm{T} 302$

$\lceil 3.23$

W300

w301

Tempering Cold Water Suppiy
-10 to $110^{\circ} \mathrm{C}\left(14\right.$ to $\left.230^{\circ} \mathrm{F}\right)$

-10 to $110^{\circ} \mathrm{C}\left(14\right.$ to $\left.230^{\circ} \mathrm{F}\right)$

$0.59 \times 10^{-3} \mathrm{~m}^{3} / \mathrm{s}$
$\left(0\right.$ to $\left.75 \mathrm{ft}^{3} / \mathrm{hr}\right)$

0 to $413.7 \mathrm{kN} / \mathrm{m}^{2}$ gauge

(0 to $60 \mathrm{psig}$ )

0 to $413.7 \mathrm{kN} / \mathrm{m}^{2}$ gauge

(0 to $60 \mathrm{psig}$ )

0 to $413.7 \mathrm{kN} / \mathrm{m}^{2}$ gauge

(0 to $60 \mathrm{psig}$ )

-10 to $40^{\circ} \mathrm{C}\left(14\right.$ to $\left.101^{\circ} \mathrm{F}\right)$

-10 to $110^{\circ} \mathrm{C}\left(14\right.$ to $\left.230^{\circ} \mathrm{F}\right)$

-10 to $110^{\circ} \mathrm{C}\left(14\right.$ to $\left.230^{\circ} \mathrm{F}\right)$

-10 to $110^{\circ} \mathrm{C}\left(14\right.$ to $\left.230^{\circ} \mathrm{F}\right)$

0.085 to $0.84 \times 10^{-3} \mathrm{~m}^{3} / \mathrm{s}$

(0-13 GPM)

\section{LEEDS \&} NORTHRUP 759

LEEDS \&

NORTHRUP 759

AMERICAN METER $A C-80$

Indicating gauge

Indicating

gauge

Indicating gauge

ARI $^{\dagger}$

ARI $^{\dagger}$

ARI ${ }^{\dagger}$

ARI ${ }^{\dagger}$

FLOW TECHNOLOGY FT-10NI5-LJ

turbine meter. Domestic

water meter

\section{System:}

EPE03: $\quad:$ Electrical poiar 0 warm air fan

$\div$ ARI R-50i72-6 FTOE-IL PTätinuti. R:J

$+\therefore$ ARI R-50171 - 24Eicr-12 Platinum E:O 


\begin{tabular}{|c|c|c|c|}
\hline MEASUREMENT & DESCRIPTION & RANGE & $\begin{array}{l}\text { SENSOR } \\
\text { MODEL }\end{array}$ \\
\hline \multicolumn{4}{|c|}{$\frac{\text { Space Heating }}{\text { System cont'd }}$} \\
\hline $\mathrm{F} 400$ & 0il flow rate to furnace & $\begin{array}{l}0 \text { to } 2.1 \times 10^{-6} \mathrm{~m}^{3} / \mathrm{s} \\
(0 \text { to } 2 \mathrm{gph})\end{array}$ & $\begin{array}{l}\text { CONAMETER } \\
\text { Series } 13 \\
\text { Oscillating } \\
\text { piston meter }\end{array}$ \\
\hline P400 & Demand loop pump discharge pressure & $\begin{array}{l}0 \text { to } 172.4 \mathrm{kN} / \mathrm{m}^{2} \text { gauge } \\
\text { (0 to } 25 \mathrm{psig})\end{array}$ & $\begin{array}{l}\text { Indicating } \\
\text { Gauge }\end{array}$ \\
\hline P401 & Demand loop pump suction pressure & $\begin{array}{l}0 \text { to } 172.4 \mathrm{kN} / \mathrm{m}^{2} \text { abs } \\
(0 \text { to } 25 \mathrm{psia})\end{array}$ & $\begin{array}{l}\text { Indicating } \\
\text { Gauge }\end{array}$ \\
\hline PD400 & $\begin{array}{l}\text { Pressure difference between fan inlet } \\
\text { ând dischürge }\end{array}$ & $\begin{array}{l}0-250 \mathrm{~N} / \mathrm{m}^{2} \\
\left(0 \text { to } \text { l"W.C. }^{\prime} \text { w.c }\right.\end{array}$ & $\begin{array}{l}\text { DWYER. } \\
\text { MAGNEHELIC } 2001\end{array}$ \\
\hline T400 & $\begin{array}{l}\text { Demand loop water exit from therinal } \\
\text { storage tank } 4.1\end{array}$ & -10 to $110^{\circ} \mathrm{C}\left(14\right.$ to $\left.230^{\circ} \mathrm{F}\right)$ & ARI $^{\dagger}$ \\
\hline T401 & $\begin{array}{l}\text { Demand loop water exit from thermal } \\
\text { storage tank } \pi 2\end{array}$ & -10 to $110^{\circ} \mathrm{C}\left(14\right.$ to $\left.230^{\circ} \mathrm{F}\right)$ & ARI $^{+}$ \\
\hline$T 402$ & $\begin{array}{l}\text { Uemand Iccp water at inlet to water- } \\
\text { to-air space heater }\end{array}$ & -10 to $110^{\circ} \mathrm{C}\left(14\right.$ to $\left.230^{\circ} \mathrm{F}\right)$ & ARI $^{\dagger}$ \\
\hline T403 & $\begin{array}{l}\text { Demand loop water at exit from water- } \\
\text { to-air space reater }\end{array}$ & -10 to $110^{\circ} \mathrm{C}\left(14\right.$ to $\left.230^{\circ} \mathrm{F}\right)$ & ARI $^{\dagger}$ \\
\hline T404 & Return air tenperature & -10 to $50^{\circ} \mathrm{C}\left(14\right.$ to $\left.120^{\circ} \mathrm{F}\right)$ & ARI $^{+}$ \\
\hline T405 & Air temperature at exit frum furnace & -10 to $65^{\circ} \mathrm{C}\left(14\right.$ to $\left.150^{\circ} \mathrm{F}\right)$ & $\operatorname{ARI}^{\dagger}$ \\
\hline Tó00 & Basement air teniperature & -10 to $50^{\circ} \mathrm{C}\left(14\right.$ to $\left.120^{\circ} \mathrm{F}\right)$ & $\operatorname{ARI}_{+}^{+}$ \\
\hline$T 602$ & First floor air temperature & -10 to $50^{\circ} \mathrm{C}\left(14\right.$ to $\left.120^{\circ} \mathrm{F}\right)$ & ARI $^{\dagger}$ \\
\hline T603 & Second floor air temperature & -10 to $50^{\circ} \mathrm{C}\left(14\right.$ to $\left.120^{\circ} \mathrm{F}\right)$ & ARI ${ }^{\dagger}$ \\
\hline$T 0400$. & $\begin{array}{l}\text { hir temperature difference across water- } \\
\text { to-dir exchanger }\end{array}$ & $0-20^{\circ} \mathrm{C}\left(0-36^{\circ} \mathrm{F}\right)$ & $\begin{array}{l}\text { 10-junction } \\
\text { type .K } \\
\text { thermopile }\end{array}$ \\
\hline TD401 & $\begin{array}{l}\text { Air temiperature difference across air neating } \\
\text { furnace }\end{array}$ & $0.50^{\circ} \mathrm{C}\left(0-50^{\circ} \mathrm{F}\right)$ & $\begin{array}{l}\text { 10-junction } \\
\text { type } K \\
\text { thermopile }\end{array}$ \\
\hline
\end{tabular}

?AR! R-50!72-6 F100-12 Platinum RTO 


MEASUREMENT
$\frac{\text { Space Heating }}{\text { System cont'd }}$
W400

\section{W400}

W401

W40?

W403

$\overrightarrow{6}$

พ404

W405

W406

W407

DESCRIPTION

RANGE

SENSOR MODEL

Demand loop water outlet from themal storage tank \#l

Demand loop water outlet from thermal storage tank \#2

Demand loop water outlet from thermal storage tank \#3

Total flow rate through demand loop

Demand loop water inlet to thermal storage tank \#1

Demand loop water inlet to thermal storage tank \#2

Demand loop water inlet to thermal storage tank \#3

Warm air total flow rate

$$
\begin{aligned}
& 0.13 \text { to } 0.64 \times 10^{-3} \mathrm{~m}^{3} / \mathrm{s} \\
& (2 \text { to } 5 \mathrm{gpm}) \\
& \text { or3 to } 0.54 \times 10^{-3} \mathrm{~m}^{3} / \mathrm{s} \\
& (2 \text { 2 } \therefore \text { : }=p . \pi)
\end{aligned}
$$

$$
0.084 \text { to } 0.84 \times 10^{-3} \mathrm{~m}^{3} / \mathrm{s}
$$$$
\text { ( } 1.3 \text { to } 13 \mathrm{gpm} \text { ) }
$$

0.13 to $0.64 \times 10^{-3} \mathrm{~m}^{3} / \mathrm{s}$ (2 to $10 \mathrm{gpm}$ )

0.13 to $0.64 \times 10^{-3} \mathrm{~m}^{3} / \mathrm{s}$ (2 to $10 \mathrm{gpm}$ )

Q.13 to $0.64 \times 10^{-3} \mathrm{~m}^{3} / \mathrm{s}$ (2 to $10 \mathrm{gpm})$

0 to $0.75 \mathrm{~m}^{3} / \mathrm{s}, 0$ to $5.6 \mathrm{~m} / \mathrm{s}$ (0 to $1600 \mathrm{cfm}, 0$ to $1100 \mathrm{fpm}$ )
BELL \& GOSSETT

TB - j"

Indicator

BELL \& GOSSETT

TB - l"

Indicator

BELL \& COSSETT

TB - I"

Indicator

INVALCO

W3/07.50

turbine meter

BELL \& GOSSETT

TB - $]^{\prime \prime}$

Indicator -

BELL \& GOSSETT

TB - I"

Indicator

BELL \& GOSSETT

TB - l"

Indicator

\section{AIR NONITOR}

$10^{\prime \prime} \times 22^{\prime \prime}$

FAN-E/ 
University of: Pennsylvania
Department of Mechanical Engineering and Applied Mechanics
Purchase Order for ESTERLINE-ANGUS Data Acquisition System

Description

Price

Model PD 2064 Key Programmable Data System

$\$ 4150.00$

3040.00

Solder Terminals

Programmable Zero Offset Range

400.00

Digital Averaging

Dual Rate Option 253

Dual Rate Channel Group Scan

24 Channels Dual Setpoints Hi-Lo Alarms

Dual Common Alarm Relays

Delete Seiko Printer

RS 232C Interface Adapted for DEC LA36-KG

Full Carriage Printing Modification for Above

Program Bank

3 Additional Files for Program Bank

Memory Save

Remote Control Connector

300.00

300.07

300.00

450.00

125.00

$-550.00$

950.00

275.00

200.00

225.00

200.00

120.00

50.00

$\begin{array}{lr}\text { Rack Slides } & 50.00 \\ \text { Manual Update Service } & 30.00\end{array}$

\begin{tabular}{lr} 
Manual Update Service & 30.00 \\
Kennedy 9832-9 Buffered Continuous 9-Track Magnetic Tape Recorder, & 6450.00 \\
\hline
\end{tabular} IBM compatible, including interface, cable, interface and system checkout.

TOTAL $\$ 17065.00$

Above prices less 5\% GSA Contract GS-00S-49174

OUR COST TOTAL \$16211.75

Same specifications as Quotations $\mathrm{PH}-146$ and $\mathrm{PH}-153$ except variuus items el iminate or added per our request.

Accuracy: $\pm .01 \%$ of full scale $\pm .015 \%$ of reading \pm 5 microvolts.

Notes: 1. Field Service is to be available in our Philadelphia office.

2. System contains one scan memory buffer for scan speed independent of output device speed.

3. The system shall scan a programmable number of the channels continuously and average them, and would scan all the channels at a programmable time interval. At that interval, it would output to the two output devices (Kennedy tape recorder and LA36 Decwriter) the average values of the continuously scanned group of channels, and the instantaneous value of the rest of the channels.

4. The LA36 Decwriter II would be drop-shipped by the University of Pennsylvania to Esterline-Angus Company for interfacing and system checkout.

Shipment: 8-10 weeks after receipt of order, at most. 